\title{
INTRALOBAR SEQUESTRATION OF THE LUNG
}

\author{
BY \\ R. ABBEY SMITH \\ From the Thoracic Surgical Unit, King Edward VII Hospital, Warwick
}

(RECEIVED FOR PUBLICATION JANUARY 21, 1955)

This paper reports four cases of a bronchopulmonary mass, supplied by an aberrant artery, occurring in the lower lobe of the lung. The object in presenting these cases is twofold; to draw attention to the diversity of the radiological picture and to discuss the effect of the systemic aberrant vessel on the production of the condition. Details of 43 cases reported since 1948 , relevant to any association that may exist between the aberrant artery and the lung change, are set out (Table I). Findlay and Maier (1951) reviewed the literature up to 1948 and collected 17 cases of aberrant arteries arising from the thoracic aorta and eight cases from the abdominal aorta. The cases reported by Pryce, Sellors, and Blair (1947) were not included in this total. Bruwer, Clagett, and McDonald (1954) concluded that 79 cases of intralobar sequestration had been described, and it is believed that the condition is a good deal more common than has hitherto been thought (Journal of the American Medical Association, 1954). Since the paper by Pryce and others (1947) the condition has been sought and more readily recognized, and to the dual abnormality the name of intralobar sequestration has been given to separate it from other developmentally similar but anatomically different conditions. The clinical features of the disease are for the most part clear-cut and the need for surgical treatment apparent. The embryology of the condition has been discussed in a number of papers.

The radiological features of these four cases were unusual in that the character of the lesion showed frequent changes during the pre-operative period of observation. The details will be described in the case reports. There is no emphasis, in the previously reported cases, on this being a common finding in the condition. Because a solid lesion becomes cystic or a cystic lesion apparently disappears, especially when in the posterior basic segment of the lower lobe, the diagnosis of sequestration seems no less likely if on other criteria this is a possibility. It was proposed in Case 3 to perform an angiocardiogram to demonstrate the aberrant vessel, but the history of the illness and the changes and location of the radiological shadow seemed to point so clearly to $\underset{0}{\overrightarrow{0}}$ the correct diagnosis that the procedure was not $i$ carried out. Precise information on the intrapul- $\vec{A}$ monary course of the aberrant artery might have $\stackrel{\vec{N}}{N}$ been gained by carrying out angiocardiography. 음 The reason for this variability in the radiological appearances in these cases was the onset of infection $\subseteq$ with the production of a communication with the normal bronchial tree.

The lung lesion has been referred to by Pryces (1946) as a bronchopulmonary mass. The exact extent and nature of the lung change which needso to be present in association with an aberrant artery for the condition to be an example of intralobar sequestration have not been clarified. Evidence of $\frac{\mathscr{Q}}{\mathscr{D}}$ actual dissociation of lung tissue away from the normally developing lung bud is not obvious in everyㅡㅡㅁ case described in the literature as examples of the condition. Certain features, such as failure of the mass to take up pigment and the presence of cartilage in the rudimentary hilum and far out in the lung periphery, strongly suggest its development free from the normal bronchial tree and therefore truly dissociated. There are instances, however, 3 in which the predominant lung change (the polycystic type) resembles chronic bronchiectasis, and it is difficult to differentiate this from chronic bronchiectasis except by the presence of a systemic artery. It is known that the aberrant artery may supply normal lung-the Type 1 artery of Pryce and others (1947)-and it is conceivable that the lung changes may result from secondary factors. N The significance of the aberrant artery in the genesis of the condition will be discussed later, and although ${ }^{\omega}$ this is of academic interest from the point of view of treatment, it may be important. In this respecte Case 4 is of outstanding interest. The changesक in the lung were of such an equivocal nature that classification of the lesion depends largely on thedefinition of the clinical entity known as intralobaro sequestration. The patient, in this case, was suffer $-\frac{?}{D}$ ing from tuberculosis of the left lower lobe and $a$ tuberculoma of the posterior basic segment wase present. A large aberrant artery ran into the lesion, 
TABLE I

SUMMARY OF REPORTED CASES

\begin{tabular}{|c|c|c|c|c|c|c|c|}
\hline Author & $\begin{array}{l}\text { Age at } \\
\text { Operation } \\
\text { and First } \\
\text { Symptom }\end{array}$ & Sex & Side & Size & $\begin{array}{l}\text { Origin } \\
\text { of Artery }\end{array}$ & $\begin{array}{l}\text { Pathology } \\
\text { of Lung Lesion }\end{array}$ & $\begin{array}{l}\text { Circulation } \\
\text { of Artery }\end{array}$ \\
\hline $\begin{array}{c}1 \\
2\end{array}$ & $\begin{array}{r}33(12) \\
5(2) \\
12(12) \\
9(7) \\
26(18) \\
16(-) \\
59(54) \\
40(20)\end{array}$ & $\begin{array}{l}\mathbf{M} \\
\mathbf{F} \\
\mathbf{M} \\
\mathbf{M} \\
\mathbf{M} \\
\mathbf{F}\end{array}$ & $\begin{array}{l}\mathbf{R} \\
\mathbf{R} \\
\mathbf{L} \\
\mathbf{L} \\
\mathbf{L} \\
\mathbf{L} \\
\mathbf{R} \\
\mathbf{L}\end{array}$ & \begin{tabular}{|l|}
$0.45 \mathrm{~cm}$ \\
0.4 \\
Large \\
$0.5 \mathrm{~cm}$. \\
Size of \\
pencil \\
$0.5 \mathrm{~cm}$. \\
0.3 \\
$2 \mathrm{~mm}$
\end{tabular} & $\begin{array}{l}\text { Uncertain } \\
\text { At dia- } \\
\text { phragm } \\
\text { Thoracic } \\
\text { aorta } \\
\text { At dia- } \\
\text { phragm } \\
\text { Thoracic } \\
\text { " } \\
\text { " } \\
\text { " }\end{array}$ & $\begin{array}{l}\text { Whole lung, upper half polycystic; lower half a } \\
\text { fibrosed mass } \\
\text { Polycystic, communication with a stem bronchus; } \\
\text { emphysematous cyst between this and normal } \\
\text { lung } \\
\text { Bronchiectatic bronchus ending blindly at rudi- } \\
\text { mentary hilum; ciliated cysts } \\
\text { Fibrosed mass with abscess cavity; squamous } \\
\text { lining } \\
\text { Distended bronchus in inflamed lung, no com- } \\
\text { munication with normal bronchial tree } \\
\text { Trabeculated single cyst in inflamed lung, lined } \\
\text { by bronchial epithelium } \\
\text { Polycystic, ciliated lining; appendage into } \\
\text { mediastinum } \\
\text { Single cyst }(8 \mathrm{~cm} .) \text { in inflamed lung, bronchial } \\
\text { epithelium lining }\end{array}$ & $\begin{array}{l}\text { To sequestration } \\
\text { only } \\
\text { To normal and } \\
\text { sequestrated lung } \\
\text { " , " }\end{array}$ \\
\hline $\begin{array}{rrr}\text { Bruwer } & \text { et } & \text { al. } \\
1^{1950)} & \\
3 & \\
4 & \\
5 & \end{array}$ & $\begin{array}{l}17(16) \\
30(27) \\
21(18) \\
27(5) \\
34(2)\end{array}$ & $\begin{array}{l}\mathbf{M} \\
\mathbf{F} \\
\mathbf{F} \\
\mathbf{F}\end{array}$ & $\begin{array}{l}\mathbf{L} \\
\mathbf{L} \\
\mathbf{L} \\
\mathbf{R} \\
\mathbf{L}\end{array}$ & $\begin{array}{l}1.0 \mathrm{~cm} \\
1.0 \\
5 \mathrm{~mm} . \\
6 \% \\
7\end{array}$ & $\begin{array}{l}\text { ", } \\
\text { Abdominal } \\
\text { aorta } \\
\text { Thoracic }\end{array}$ & $\begin{array}{l}\text { Dilated bronchi; no pigmentation } \\
\text { Polycystic; one node pigmented } \\
\text { Large cyst } \\
\text { Large cyst with surrounding fibrosis; no } \\
\text { pigmentation } \\
\text { Polycystic, no pigment }\end{array}$ & $\begin{array}{l}\text { To sequestration } \\
\text { only } \\
\text { In relationship to } \\
\text { cyst walls; free } \\
\text { communication } \\
\text { with pulmonary } \\
\text { artery (by water } \\
\text { injection method) }\end{array}$ \\
\hline $\begin{array}{c}\text { Cole et al. (1951): } \\
2 \\
3 \text { and } 4 \\
5 \\
6\end{array}$ & $\begin{array}{l}20(12) \\
43(29) \\
\text { Artery fro } \\
28 \text { (5) } \\
3 \text { (3) }\end{array}$ & $\begin{array}{l}\mathbf{m} \text { abc } \\
\mathbf{M}\end{array}$ & $\underset{\mathbf{L}}{\operatorname{minal}}$ & \begin{tabular}{|}
$\mid 1.0 \mathrm{~cm}$. \\
$\mid 1.5$ \\
$\mid$\begin{tabular}{c|}
$5 \mathrm{~mm}$. \\
aorta to no
\end{tabular}
\end{tabular} & $\begin{array}{l}", \\
", \\
\text { rmal lower lo } \\
\text { Thoracic } \\
,\end{array}$ & \begin{tabular}{|l|} 
Cyst $(6 \mathrm{~cm}$.) with bronchial communication \\
\\
Cyst $(6 \mathrm{~cm}$.) lined by respiratory epithelium, sur- \\
rounded by inflamed lung; small pulmonary \\
artery \\
of (right) \\
Cyst $(9 \times 5 \times 4 \mathrm{~cm}$.) adjacent bronchiectasis \\
Polycystic, like dilated bronchi ? communica- \\
tion with bronchial tree
\end{tabular} & $\begin{array}{l}\text { Communication } \\
\text { with pulmonary } \\
\text { artery in normal } \\
\text { and sequestered } \\
\text { lung }\end{array}$ \\
\hline $\begin{array}{l}\text { McDowell et al. } \\
\text { (1951): } 1\end{array}$ & $8(6)$ & $\mathbf{M}$ & $\mathbf{R}$ & $5 \mathrm{~mm}$. & , & Polycystic, small pulmonary artery & To cystic area only \\
\hline $\begin{array}{l}\text { Tosatti and Gravel } \\
(1951): 1\end{array}$ & $\begin{array}{ll}23 & (6) \\
5 & (3)\end{array}$ & $\mathbf{M}$ & $\mathbf{L}$ & $\begin{array}{ll}6 & \prime \prime \\
4 & \end{array}$ & , & $\begin{array}{l}\text { Single cyst in apical R.L.L., numerous smaller } \\
\text { cysts, lined by bronchial epithelium; tuber- } \\
\text { culosis } \\
\text { Polycystic, intercommunicating, connected with } \\
\text { basal bronchi, lined by respiratory epithelium. } \\
\text { Ill-defined mass }\end{array}$ & $\begin{array}{l}\text { Free anastomosis } \\
\text { with pulmonary } \\
\text { artery }\end{array}$ \\
\hline $\begin{array}{c}\text { Kergin (1952): } \\
1 \\
2\end{array}$ & $\begin{array}{l}60(55) \\
34(24) \\
16\left(1 \frac{1}{2}\right)\end{array}$ & $\begin{array}{l}\mathbf{M} \\
\mathbf{F}\end{array}$ & $\begin{array}{l}\mathbf{L} \\
\mathbf{L}\end{array}$ & $\begin{array}{c}\begin{array}{c}\text { Two each } \\
3 \mathrm{~mm} .\end{array} \\
6 \mathrm{~mm} . \\
3 "\end{array}$ & $\begin{array}{l}\text { " } \\
\text { Abdominal } \\
\text { Thoracic } \\
\text { Abdominal } \\
\begin{array}{c}\text { 7th inter- } \\
\text { costal }\end{array}\end{array}$ & $\begin{array}{l}\text { Polycystic draining into L.L.L. bronchus; res- } \\
\text { piratory epithelial lining; no pigment } \\
\text { Large single cyst communicating with L.L.L. } \\
\text { bronchi; bronchial epithelial lining, no pig- } \\
\text { ment } \\
\text { Large cyst with smaller cysts in rubbery mass, } \\
\text { communication with R.L.L. bronchus; no } \\
\text { pigment } \\
\text { Same as 3; artery small } \\
\text { Cyst }(8 \mathrm{~cm} \text {.) in R.L.L. with rubbery cystic append- } \\
\text { age pedicled to R.L.L.; epithelial lining; no } \\
\text { pigment }\end{array}$ & $\begin{array}{l}\text { Drained into pul- } \\
\text { monary vein; no } \\
\text { pulmonary artery } \\
\text { to sequestration } \\
\text { Vein } 3 \text { mm. drain- } \\
\text { ing into vena } \\
\text { azygos } \\
\text { Free drainage into } \\
\text { pulmonary vein } \\
\text { From appendage } \\
\text { along pedicle to } \\
\text { main cyst }\end{array}$ \\
\hline
\end{tabular}


TABLE I-continued

\begin{tabular}{|c|c|c|c|c|c|c|c|}
\hline Author & $\begin{array}{l}\text { Age at } \\
\text { Operation } \\
\text { and First } \\
\text { Symptom }\end{array}$ & Sex & Side & Size & $\begin{array}{l}\text { Origin } \\
\text { of Artery }\end{array}$ & $\begin{array}{l}\text { Pathology } \\
\text { of Lung Lesion }\end{array}$ & $\begin{array}{l}\text { Circulation } \\
\text { of Artery }\end{array}$ \\
\hline Santy et al. (1952): & & & & & & & \multirow{6}{*}{$\begin{array}{l}\text { Drainage into inte } \\
\text { costal vein } \\
\text { To sequestrated } \\
\text { area only }\end{array}$} \\
\hline & $14(4)$ & $\mathbf{F}$ & $\mathbf{L}$ & $8 \mathrm{~mm}$. & Thoracic & 3 cysts in dense whitish-yellow tissue; epithelial & \\
\hline 2 & $10(1)$ & $\mathbf{F}$ & $\mathbf{L}$ & Size of & , & Polycystic; nut-size cyst, multiple smaller cysts & \\
\hline 3 & $21(?)$ & $\mathrm{F}$ & $\mathbf{L}$ & $\begin{array}{l}\text { radial } \\
\text { Two, } 6 \\
\text { mm. and }\end{array}$ & ," & Single cyst in dense white non-pigmented tissue & \\
\hline 4 & $22(18)$ & $\mathbf{M}$ & $\mathbf{R}$ & $\begin{array}{l}6 \mathrm{~mm} . \\
\text { Large }\end{array}$ & Thoracic and & Orange-size cyst resembling chronic abscess & \\
\hline 5 & $8(2)$ & $\mathbf{M}$ & $\mathbf{R}$ & Size of & $\begin{array}{l}\text { intercostal } \\
\text { Thoracic }\end{array}$ & $\begin{array}{l}\text { prolongation toward mediastinum } \\
\text { Single cyst }\end{array}$ & \\
\hline 6 & $45(39)$ & $\mathbf{M}$ & $\mathbf{R}$ & $\begin{array}{l}\text { radial } \\
\text { Two, } 5 \\
\text { mm. and } \\
5 \mathrm{~mm} .\end{array}$ & , & $\begin{array}{l}\text { Polycystic; one large, surrounded by dense white } \\
\text { tissue, area totally dissociated; no pigment }\end{array}$ & To cystic area onl \\
\hline $\begin{array}{l}\text { Wyman and Eyler } \\
(1952): 1\end{array}$ & $54(54)$ & $\mathbf{M}$ & L & 8, & ," & $\begin{array}{l}\text { Multilocular cyst }(9 \mathrm{~cm} .) \text { surrounding fibrosis and } \\
\text { pneumonitis }\end{array}$ & \multirow{7}{*}{$\begin{array}{l}", ", ", \\
\text { To cystic and } \\
\text { normal lung }\end{array}$} \\
\hline 2 & $27(27)$ & M & $\mathbf{L}$ & 5, & , & Multilocular cyst $(6 \mathrm{~cm}$.) surrounded by cystic & \\
\hline 3 & $51(47)$ & $\mathbf{M}$ & $\mathbf{L}$ & $\begin{array}{c}\text { Two, 2 } \\
\text { mm. and }\end{array}$ & Abdominal & $\begin{array}{l}\text { Unilocular cyst; no communication with bron- } \\
\text { chus; associated diaphragmatic hernia }\end{array}$ & \\
\hline 4 & $15(13)$ & $\mathbf{M}$ & $\mathbf{R}$ & $\begin{array}{l}5 \mathrm{~mm} \text {. } \\
\text { Size of }\end{array}$ & Thoracic & Innumerable cysts; no communication with & \\
\hline 5 & $33(31)$ & $\mathbf{F}$ & $\mathbf{L}$ & $4 \mathrm{~mm}$. & ", & $\begin{array}{l}\text { Trabeculated cyst }(7 \mathrm{~cm} .) \text {; surrounding fibrosis } \\
\text { and atelectasis; no fissure between L.U.L. }\end{array}$ & \\
\hline 6 & $5(5)$ & $\mathbf{M}$ & $\mathbf{R}$ & 3, & Abdominal & $\begin{array}{l}\text { Polycystic with surrounding cholesterol pneu- } \\
\text { monitis }\end{array}$ & \\
\hline 7 & $15(6)$ & $\mathbf{M}$ & $\mathbf{L}$ & 4, & Thoracic & Multilocular cyst & \\
\hline$\underset{(1954): 1}{\text { Bruwer }}$ al. & $60(23)$ & $\mathbf{M}$ & $\mathbf{R}$ & 0.8, & , & Cyst $(6 \mathrm{~cm}$.), ciliated columnar lining; surround- & \multirow[t]{5}{*}{$\begin{array}{c}\text { Distributed aroun } \\
\text { cyst }\end{array}$} \\
\hline 2 & $36(36)$ & $\mathbf{F}$ & $\mathbf{R}$ & $1:-$ & , & Single cyst & \\
\hline 3 & $23(23)$ & F & L & $\begin{array}{l}1 \text { large } \\
2-3 \text { small }\end{array}$ & ", & $\begin{array}{l}\text { Large bronchogenic cyst with surrounding lipoid } \\
\text { pneumonitis }\end{array}$ & \\
\hline 4 & $18(18)$ & $\mathbf{M}$ & L & $1.5 \mathrm{~cm}$. & , & $\begin{array}{l}\text { Bronchogenic cyst }(10-12 \mathrm{~cm} \text {.) with surrounding } \\
\text { inflammatory reaction; sharp margin from } \\
\text { normal lung }\end{array}$ & \\
\hline 5 & $57(51)$ & $\mathbf{M}$ & $\mathbf{R}$ & Large & , & $\begin{array}{l}\text { Large trabeculated bronchogenic cyst; small } \\
\text { bronchial structures adjacent; no communica- } \\
\text { tion with R.L.L. bronchi }\end{array}$ & \\
\hline Present series: & $6\left(2 \frac{1}{2}\right)$ & F & $\mathbf{R}$ & Several & Intercostal & Polycystic, surrounding bronchiectasis & \multirow{4}{*}{$\begin{array}{l}\text { To major cyst onl } \\
\text { no communic } \\
\text { tion with p } \\
\text { monary artery } \\
\text { Branches to norm } \\
\text { lung; free con } \\
\text { munication wi } \\
\text { pulmonary vein } \\
,, \text {, }\end{array}$} \\
\hline 2 & $24(18)$ & F & $\mathbf{L}$ & $\begin{array}{l}\text { small } \\
0.4 \mathrm{~cm} \text {. }\end{array}$ & Abdominal & $\begin{array}{l}\text { Unilocular trabeculated cyst }(4 \mathrm{~cm} \text {.) with smaller } \\
\text { cysts and fibrosis, partly lined by bronchial } \\
\text { epithelium }\end{array}$ & \\
\hline 3 & $10(9)$ & F & $\mathbf{R}$ & 1.0, & Thoracic & $\begin{array}{l}\text { Multiple infected cysts communicating with } \\
\text { bronchial tree; no pigment }\end{array}$ & \\
\hline 4 & $39(38)$ & $\mathrm{F}$ & $\mathbf{L}$ & 1.0, & , & $\begin{array}{l}\text { Multiple infected cysts; massive caseation and } \\
\text { T.B. bronchiectasis; pigment present }\end{array}$ & \\
\hline
\end{tabular}

and, whether it represents an example of intralobar sequestration with superimposed tuberculosis, or tuberculous bronchiectasis in an otherwise normal lobe supplied by an aberrant artery, is uncertain.

\section{CASe RePorts}

CASE 1.-S. J., a girl born in 1944, was referred to hospital for the first time when 2 years old because of persistent cough following pneumonia. The Mantoux test was negative and a chest radiograph normal. The cough was thought to be due to an upper respiratory infection. She remained reasonably well for the next three years, but was never completely free of chest symptoms. Shê was referred again to hospital at the age of 5 with ap exacerbation of her bronchitis. A radiograph showe collapse of the right lower lobe, which persisted. foreign body was suspected, and the child was bronchoo scoped. Apart from a good deal of foul pus in the right lower lobe bronchus, the view was normal. A cavit. appeared in the lower lobe lesion in a film two week later, a month later the shadow disappeared, and if another month the lower lobe lesion seemed solid (Fig. 1) It was situated in the posterior basic segment an seemed to be above the diaphragm. A barium meat examination showed no evidence of a diaphragmate 


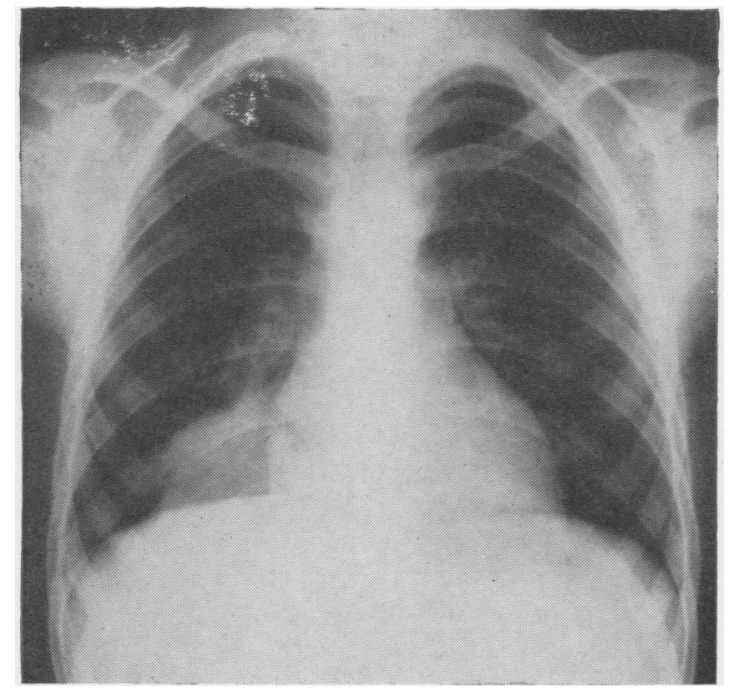

FIG. 1.-Radiograph showing solid lesion in the right lower lobe. A cavity was visible in a pre-operative film.

hernia. The bronchogram was within normal limits except for some deficient filling of the terminal bronchus of the posterior basic segment bronchus. A presumptive diagnosis of sequestrated lung was made in 1950.

The child was operated on, aged 6, by Mr. Leigh Collis. At operation the right lower lobe was free except posteriorly, where it appeared to grow into the parietal pleura. The lobe received several vascular connexions at this point from an intercostal artery. There was no vessel from the aorta. The intralobar mass was in the posterior basal segment. The vascular abnormality made resection of the basal segments impossible and the whole right lower lobe was removed. Convalescence was uneventful and the child has been symptom-free since operation.

Pathological examination showed the lesion to be a cystic mass in the posterior basic segment of the lower lobe. The cysts were multiple and there was considerable fibrosis around the cysts. The segmental divisions of the lobar bronchi were normal and the cystic area was in communication with the bronchial tree. There was considerable inflammatory reaction in the surrounding tissue. The aberrant arterial branches supplied the cystic area only; no definite communication with the pulmonary artery was demonstrable. The mass was not pigmented.

CASE 2.-V. H., a housewife aged 24, complained of cough and pain in the left chest for the previous three weeks. The cough was associated with up to $5 \mathrm{oz}$. of brownish, foul-tasting sputum, and the patient had been pyrexial. She had had one or more similar attacks for the previous six years during the winter months, but none were severe enough for her to consult her doctor. Pain in the left side of the chest was present on each occasion. There had been no haemoptysis. No abnormal physical signs were found in the chest or elsewhere on examination. A radiograph of the chest is shown (Fig. 2); on a film of less penetration the two shadows behind the heart were not visible. The abnormal shadows were located to the posterior basic segment on a lateral film. Shortly after this film was taken a fluid level was noted in the larger of the shadows. A bronchogram showed no abnormality and the cyst could not be filled with "lipiodol." At bronchoscopy a fair amount of foul pus in the left lower lobe was sucked out. A barium meal examination and the Casoni test were normal. A presumptive diagnosis of intralobar sequestration was made.

At operation there seemed to be a complete absence of inflammatory reaction. The fissure was free and there were no adhesions. The pleura over the posterior basic segment was not thickened and no definite mass could be felt in the lower lobe. An aberrant artery coming from below the diaphragm and running into the lung was tied. It was of sufficient length to divide without difficulty. In mobilizing the lower lobe a cystic space in the lung was opened and about $100 \mathrm{ml}$. of viscid fluid removed. There was no demonstrable bronchopleural fistula between the cyst wall and the pleural cavity. An attempt at local resection of the cyst was made, but its connexions with the anterior basic segments made this impracticable. The pulmonary artery to the lower lobe was noted to be the same size as the vessel to the posterior segment of the upper lobe. The basal segments of the left lower lobe were resected. The convalescence was straightforward.

Examination showed the principal lesion in the lung to be a cyst some $4 \mathrm{~cm}$. in diameter (Fig. 3) in the

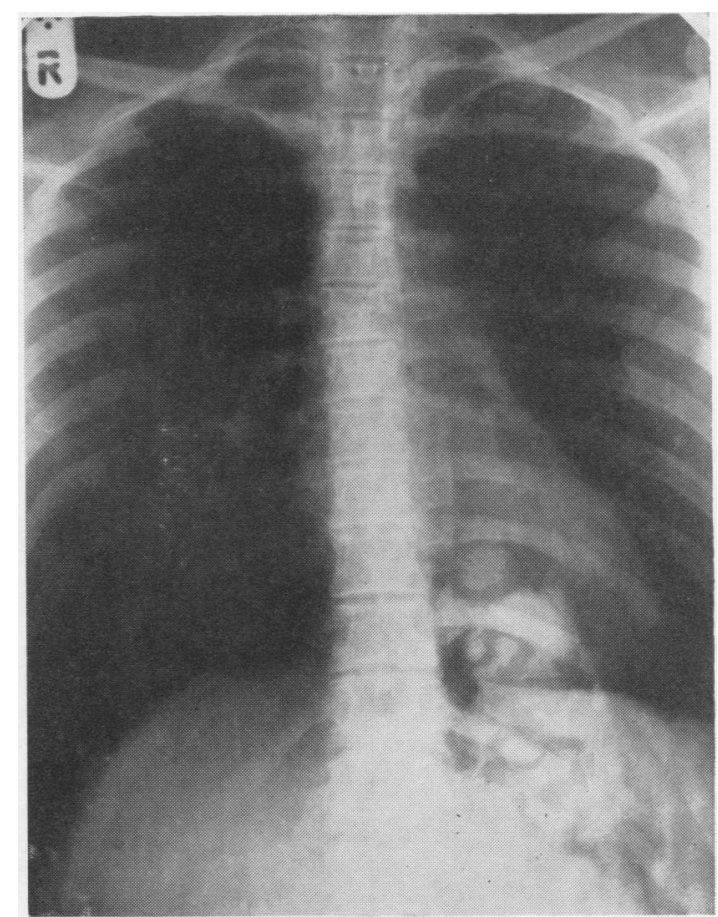

Fig. 2.-Radiograph showing solid lesions in left lower lobe. Not visible in a film of normal penetration. A fluid level appeared in a later film. 


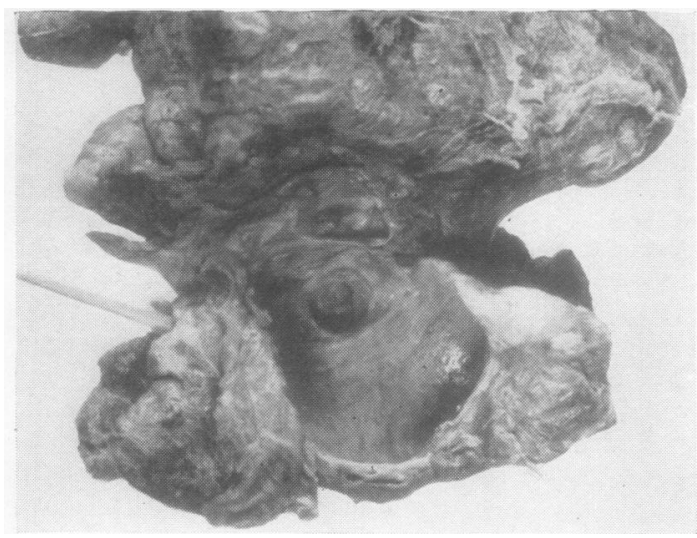

Fig. 3.-The cyst in Case 2, with a probe in the aberrant artery. Some fibrosis around the cyst is seen.

posterior basic segment. There were small adjacent cystic areas and considerable fibrosis around. The aberrant artery measured $0.4 \mathrm{~cm}$. in diameter; it entered the lobe from the free edge of the pulmonary ligament, and was distributed around the major cyst. This was confirmed by injection. There were no obvious communications with the pulmonary artery or vein, but it branched as soon as it entered the lobe. Microscopically the cyst was lined by a denuded basement membrane, but in a recess of the cyst a group of tall columnar cells was seen. There was some submucous round-cell infiltration. The pulmonary artery showed no abnormality. The aberrant artery was of the elastic type and was not sclerotic.

CASE 3.-R. W., a girl aged 10, suffered from pyrexia, cough, and cyanosis on and off for eight months before

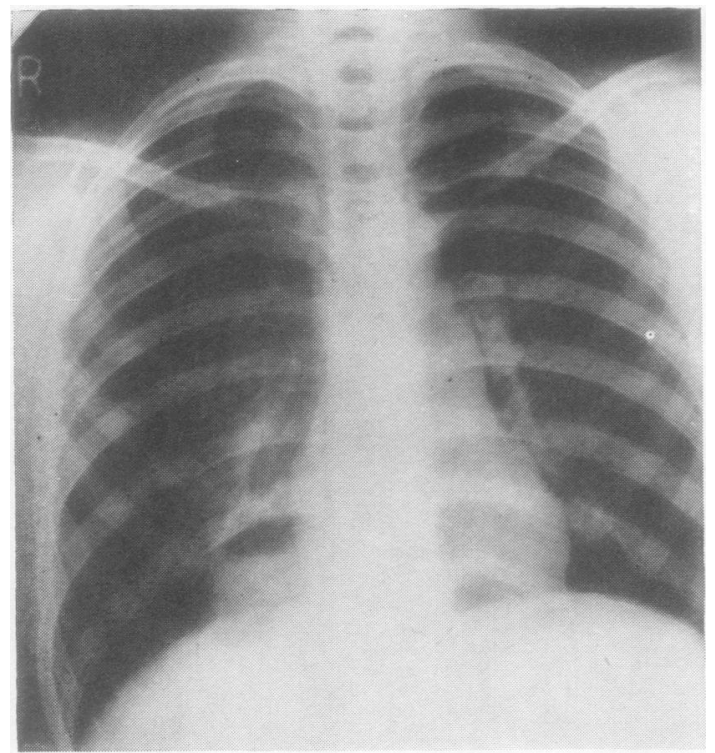

FIG. 4.-Radiograph showing a cyst in the right lower lobe. A later film showed a normal appearance. being seen. She had been confined to bed several times since the onset of symptoms but never previously:0 There was considerable purulent sputum but nơ haemoptysis. She had received chemotherapy withouts lasting benefit. There was no relevant previous history $\overrightarrow{\mathbb{D}}$ Examination showed a normally developed child 0 Persistent crepitations at the right base were presents Radiography of the chest over the period she had beerb observed showed an apparently solid mass in the right lower lobe, later a cystic mass with a fluid level (Fig. 4) $\overrightarrow{\mathfrak{\omega}}$ and later still a normal film. A bronchogram was noe performed and bronchoscopy showed a normal visible bronchial tree. On the child's history and the evidence of a changing shadow in the radiograph, a presumptive diagnosis of intralobar sequestration was made.

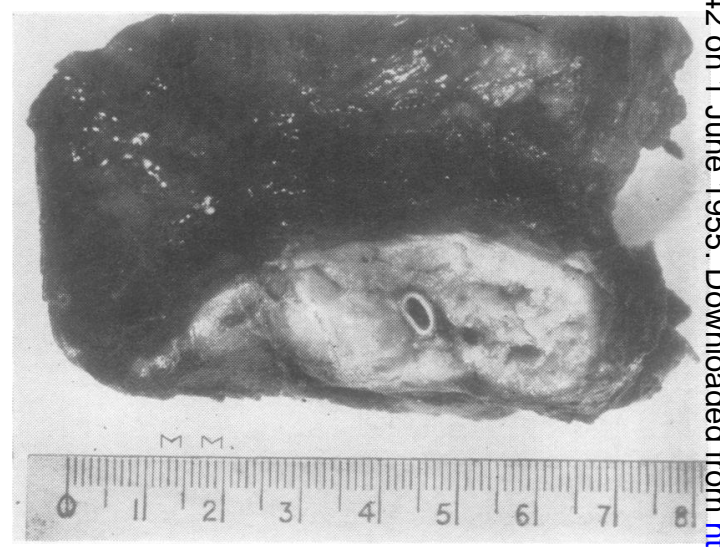

FIG. 5.-The lobe (Case 3). The collar of fibrous tissue around the aberrant vessel is shown.

At operation the pleural cavity was free. An irregulab mass of uneven consistency filled the posterior basio segment of the right lower lobe. This mass blended into the adjacent segments. There was no fissure between the upper and lower lobes. Considerable secretion wass squeezed out of the lobe while it was being freed, an for a time it was difficult to maintain the child's colour. A large aberrant vessel emerged from the mediastinunf $2.5 \mathrm{~cm}$. below the inferior vein and entered the lobes It ran in front of the oesophagus and from its direction it seemed certain it originated in the thoracic aorta. portion of the lower lobe mass was carried into the mediastinum with the vessel. The pulmonary artery to the right lower lobe was roughly half normal size. AN right lower lobectomy was performed. Difficulty was encountered in ligating the aberrant artery because of the portion of the lower lobe surrounding the artery an $\$$ the short length of artery available between the lung an $\Phi$ the wall of the oesophagus. Convalescence was uneventfuf and the child is symptom free.

The specimen consisted of the whole lower lobe. There was an area of firm white tissue in the posterior basig segment which was indefinitely demarcated from normal apical and anterior basic segment. The affecte\& area contained a number of cysts, the largest some $2 \mathrm{cms}$ in diameter, in communication with the bronchial tree An artery $1 \mathrm{~cm}$. in diameter entered this mass (Fig. 5p 


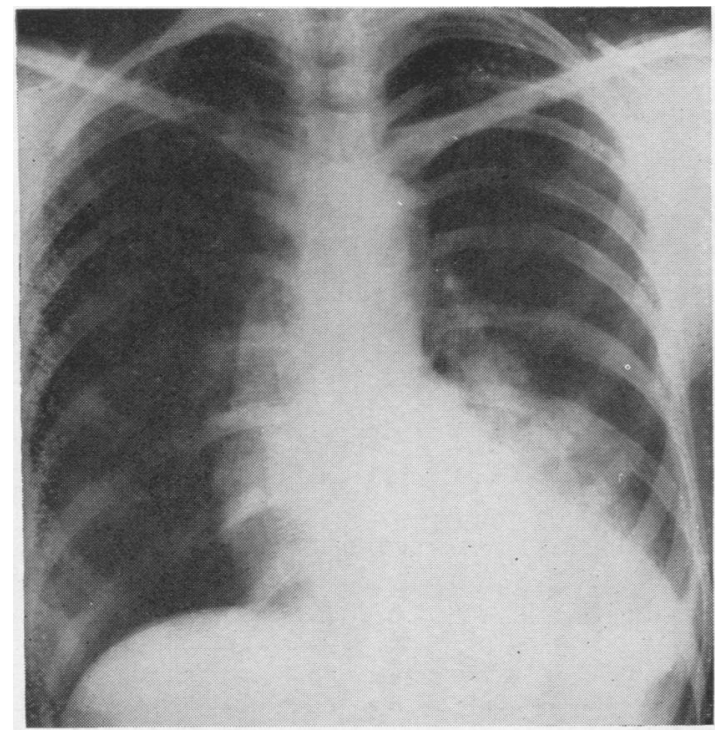

FIG. 6.-Radiograph showing tuberculosis of the left lower lobe. A radiograph following streptomycin therapy showed normal appearances.

branched within the mass, and was distributed to it. It ran to the normal lung, but no communication with the pulmonary artery was demonstrable. Pigment was not present in the affected segment. Microscopically the matrix of the relevant portion of the lung was made up of fibrous tissue. In this a number of bronchial structures were present but no alveoli. The largest bronchi showed a ciliated epithelium; many of the smaller ones were lined by cuboidal epithelium. Nowhere was bronchial muscle evident. Beneath the epithelium there were collections of lymphocytes, in places aggregated into wellformed follicles with germinal centres. Most of the bronchi contained inflammatory cells and exudate. The blood vessels were not especially numerous and appeared normally formed. The picture suggests a chronic bronchiectasis.

The aberrant artery entered the lobe in relation to lymphoid tissue. The tunica adventitia and media were well developed. There was a well-developed internal elastic lamina. The elastic fibres coursed in the tunica media and continued into the internal and external elastic laminae. The vessel showed no evidence of pathological change. The pulmonary artery and vein were microscopically normal.

Case 4.-B. H., a housewife aged 39, was admitted to hospital 14 months before operation with left-sided pneumonia. A left-sided pleural effusion, which was sterile on culture, was aspirated on one occasion and it did not recur. A chest radiograph (Fig. 6) showed a confluent tuberculous lesion in the left lower lobe with scattered lesions in both upper zones. Only one sputum positive for tubercle bacilli was obtained on direct examination. Culture of the gastric washings was negative. She was treated by bed rest for four months, and

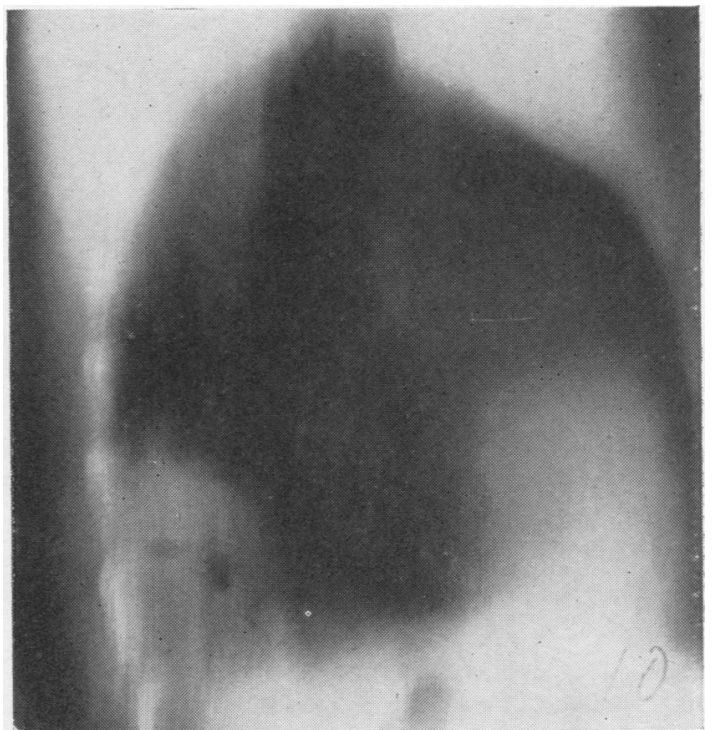

Fig. 7.-Lateral tomogram (left) of Case 4 at the same time as the normal plain film. Two cysts are shown in a solid mass in the posterior basic segment.

then given streptomycin and isoniazid. On this treatment the chest radiograph returned to normal; there was, however, a persistent shadow in the left posterior basic segment which was most easily seen in the lateral tomogram (Fig. 7). A number of cavities or cystic spaces were noted in this otherwise solid-looking shadow. It was thought to be a residual tuberculous lesion and operation for its removal was advised. Pre-operative bronchoscopy showed no abnormality. The patient was symptom free and there were no physical signs at this time. A pneumoperitoneum was induced a week before operation.

At operation the pleural cavity was free and no signs of the effusion could be found. The posterior basic segment of the lower lobe contained a hard, bulky mass which blended into the surrounding normal lung. The apical segment of the lower and the left upper lobe were normal. The pulmonary ligament was thickened and contracted and the lobe was adherent to the mediastinum and diaphragm. The pulmonary artery was dissected and it was then seen that the lower lobe artery was no bigger than the vessel to the lingula. This suggested the possibility of an aberrant supply to the lobe. The pulmonary ligament was examined and a thick, short artery was palpated and later seen arising from the aorta $3 \mathrm{~cm}$. below the level of the inferior vein and entering the lower lobe. With difficulty this vessel was secured and the whole lower lobe removed. The patient convalesced normally.

The specimen consisted of a lower lobe. On the mediastinal surface of the posterior lower two-thirds a large vessel of arterial type entered the lung tissue about $3 \mathrm{~cm}$. inwards from the margin (Fig. 8). At the cut level the vessel was $1 \mathrm{~cm}$. diameter. The hilum of the lobe showed an apparently normal bronchus, pulmonary 


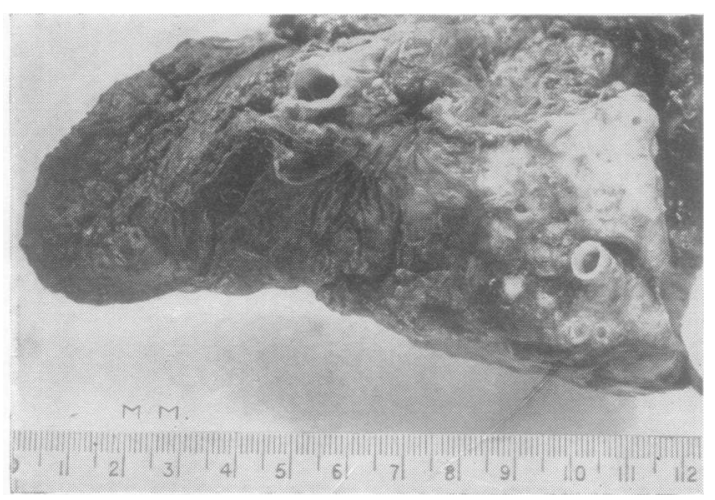

Fro. 8.-Left lower lobe (Case 4). The artery is seen entering a cystic structureless mass and its size may be compared to that of the normal lower lobe bronchus.

artery and vein, and several lymph nodes, some of which contained tuberculous lesions.

The cut surface showed a division between normal and abnormal lung tissue. The latter was whitish-grey, tough and fibrous with a large number of dilated bronchus-like structures. At least one of these, almost in the centre of the specimen, had become cyst-like, approximately $1.5 \mathrm{~cm}$. in diameter. Most of the bronchi contained white necrotic exudate. A fair amount of black pigment was present near the surface and near the junction between normal and abnormal lung tissue in the fibrotic area.

Serial slicing showed the large vessel to branch very shortly after entering the lung, with secondary branching soon afterwards. Very obvious atheromatous plaques were present in the wall hereabouts. No obvious main bronchus existed in relation to the vessel, neither could a main bronchus be shown to connect the abnormal lung to the lobar hilum. Such bronchial branchings as could

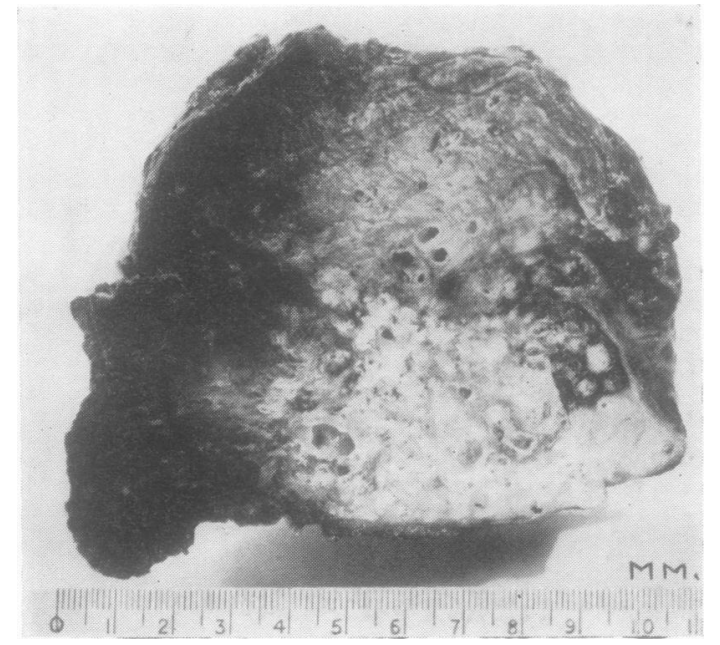

FiG. 9.-Cut section (Case 4) shows the cystic spaces and caseation. The ill definition from normal lung tissue is demonstrated. be traced from the hilum appeared to skirt the abnormally connected lung mass. No large vein accompanied the abnormal artery.

The whole of the abnormally connected lung mass appeared to be extensively involved by tuberculosis, while no naked-eye evidence of this could be found in the normally connected parts of the lobe.

Microscopy.-A variably thick band of fibrous tissue seemed to be the junction of the sequestrated lung mass with the rest of the lobe. The parenchyma was virtually completely replaced by tuberculous granulation tissue, mainly in the form of giant cell systems, but occasionally as fibrocaseous foci. Within this dense tissue were dilated, bronchus-like structures composed of an outer ring of rather incomplete plain muscle and a lining of usually intact ciliated columnar epithelium. In $\vec{N}$ only two instances was bronchial cartilage seen associated with such a structure. In almost all of them a wide zone of giant cell systems separated the epithelium from the muscle. No mucous glands were present. In areas where fibrosis of parenchyma was present much condensation of elastic fibres could be demonstrated. Carbon pigment was present, but seemed confined to $G$ lymphoid elements suggesting carriage from normally connected lung.

Apart from collapse and some congestion (? operative), the parenchyma of the normal left lower lobe was virtually normal. Its freedom from tuberculous disease was most remarkable. Tuberculosis was present only in the hilar lymph glands, and there considerable healing in the form of collagenization had taken place.

The aberrant artery was an elastic artery with considerable atheroma and intimal proliferation. It was noteworthy that the atheroma disrupted the elastic fibres and incorporated the fragmented elastica within the deposits. This process became less obvious as the branches became smaller.

The muscular arteries (presumably branches of the normal bronchial artery) showed intense endarteritis obviously associated with the degree of chronic fibrocaseous tuberculosis in the surrounding tissue. The branches of the elastic artery appeared relatively immune from this change.

The veins appeared perhaps dilated but structurally within normal limits.

Ziehl-Neelsen staining showed A.F.B. to be extremely مू scanty.

\section{Discussion}

If consideration of the aberrant artery to 0 sequestered lung tissue is confined to the vessel arising from the aorta and entering the lower lobe of the lung, the theory of sequestration proposed by Pryce (1946) and Pryce and others (1947) is the one $\square$ most widely accepted. This theory has been disputed. Baar and d'Abreu (1949) do not accept the artery as the primary abnormality, and set out reasons for this belief. Cole, Alley, and Jones (1951) consider the most likely explanation of the combined abnormality to be some interference with the 
embryonic development in the region behind the heart and that any structure in that area may suffer. Bruwer and others (1954), in the section of their paper on the embryology and pathogenesis of the condition, put forward alternative suggestions which they consider are not necessarily incompatible with Pryce's (1946) theory. In their paper these authors point out the great difficulty in determining exactly what anastomosis takes place between the aberrant artery and the supposed normal pulmonary artery and vein. Whether or not this aberrant vessel functions as a bronchial artery is uncertain, but in order to indicate the possible influence of the aberrant artery on the structure of the lobe to which it runs, it is necessary to refer briefly to the bronchial artery circulation.

Bronchial Arterial Circulation.-An anastomosis between the pulmonary and the bronchial (from the aorta) circulations has been recognized for many years. The precapillary anastomosis between the two circulations has been demonstrated and described by Cockett and Vass (1950) and the mechanism referred to as a bronchopulmonary shunt. The extent of the shunt is in part dependent upon the normality or otherwise of the lung in which the anastomosis takes place. This work has been confirmed by Tobin (1952). There seems no doubt that in normal health this anastomosis is sufficient to prevent necrosis of bronchial cartilage and lung changes around the bronchus after experimental occlusion of the bronchial arterial system (Ellis, Grindley, and Edwards, 1951). These authors did find, however, that occlusion of the bronchial artery produces necrosis of the extrapulmonic bronchus; this indirectly demonstrates the importance of the shunt in maintaining the viability of the intrapulmonary bronchi. Ellis and others (1953) were unable to draw conclusions from experiments on the influence of defective bronchial circulation in the development of bronchiectasis. Ameuille and Mézard (1933) and Ameuille and Lemoine (1934) were the first to associate the changes in bronchiectasis with bronchial artery deprivation. Work by Cudkowicz and Armstrong (1953) is of importance in this respect. Investigating the relationship of pulmonary emphysema to changes in the bronchial arterial circulation they found that in extreme instances of bronchopulmonary anastomosis the bronchi and lung tissues show severe atrophy and fibrosis, while part of the pulmonary artery bed serves as a route for arterial blood to reach the proliferating collagen in the atrophic lung areas. They also state that with the establishment of permanent massive anastomosis the high pressure blood in the bronchial arteries would appear to by-pass the peripheral bronchial artery tree, which could lead to changes in the structure of the lung and regression of the peripheral bronchial arteries.

It would seem, therefore, that under certain circumstances the freer the anastomosis between the bronchial and the pulmonary systems the more likely are lung changes. Cockett and Vass (1950) found increased bronchial circulation and pulmonary hypertension associated with bronchiectatic changes in the lobe involved. Liebow, Hales, and Lindskog (1949) described the association of severe bronchiectasis with a great increase in the bronchopulmonary anastomosis. Reporting on cases of absent and hypoplastic pulmonary arteries, Maier (1954) described a child with an absent pulmonary artery and a very dilated bronchial arterial system supplying the lung. The lung, on pathological examination after operation, showed diffuse fibrosis and thickening of the interalveolar septa. There was little evidence of infection to account for these changes. While further data must be awaited, it seems reasonable to state that there is some evidence of an association between an increase in the bronchial (aortic) circulation to a lobe and changes in the lobe such as bronchiectasis, fibrosis, and lung parenchymal atrophy.

Nature and Effects of the AberRant Artery Circulation.- - The evidence for and against considering the aberrant artery to be a bronchial vessel will not be discussed. On embryological grounds and because of the systemic pressure within the artery it should be regarded as bronchial; histologically it has the elastic structure of a pulmonary artery, and Pryce (1946) described the aberrant vessel as a pulmonary and bronchial artery combined. Bruwer and others (1954) take the view that in the aberrant arteries methods of communication with the pulmonary system of vessels should be regarded as bronchial arteries. If this anastomosis between pulmonary and aberrant artery were free and widespread it might be expected that in some instances atheromatous change in the pulmonary artery would occur similar to the changes found in this vessel in patency of the ductus arteriosus. There is no evidence, from examination of the reported cases of sequestrated lobes with aberrant artery, either that the systemic blood flow produces enlargement of the pulmonary artery or that atheromatous changes ever occur in this vessel. On the contrary the usual finding is that the pulmonary artery is of normal or less than normal size. In three of the four cases described in this series, the pulmonary artery to the affected lobe was markedly reduced in size, and this was 
deliberately looked for as a confirmatory sign of the presence of an aberrant supply to the lobe. The active tuberculous lesions in the lobe and adjacent lung tissue in Case 4 are infrequently seen where pulmonary hypertension exists. The association of sequestrated lung and tuberculosis has been previously described (Tosatti and Gravel, 1951). These authors, however, were able to demonstrate, by digestion of the lung tissue in the post-operative specimen, a communication between the aberrant and pulmonary artery. Neither vessel showed atheromatous change. While some communication must exist, the evidence is against the pulmonary arterial system being the principal channel into which the aberrant flow is dissipated.

There is little information available on how this large systemic flow enters the pulmonary venous system. There are no reports in the literature of sequestrated lungs in which large communicating blood spaces were visible as are seen in pulmonary arteriovenous fistulae. Changes in the pulmonary vein, the so-called "arterialization" of the vein wall, were looked for in the cases described in this series and could not be found. Thickening of the vein wall is a constant finding in long-standing direct arteriovenous communications. The magnitude of the anastomosis that does, however, take place between the aberrant artery and the pulmonary vein can be easily confirmed by a simple manœuvre at operation.

It is assumed that this anastomosis takes place through the channels similar to those occupied by the aberrant bronchial system of vessels described by Cudkowicz and Armstrong (1953), and that the flow is thence through the peripheral pulmonary capillaries into the pulmonary vein. The procedure which was carried out in Cases 3 and 4 was as follows. The pulmonary artery was ligated and divided, the inferior vein ligated centrally, and a clamp placed on the lung side of this vessel. The lobe is then isolated except for its aberrant supply. If the clamp on the vein is released blood flows freely from it for as long as the aberrant artery is allowed to remain patent. By this safe and controllable procedure the extent of the systemic blood flow through the lung can be appreciated. It seemed comparable in volume to the flow from a systemic artery of similar size to the aberrant vessel. The vessels in Cases 3 and 4 (Figs. 5 and 8) were alike in size to the subclavians and clearly took a much greater share of the output of the left heart than the $1 \%$ which is the normal bronchial vessels' share (Madoff, 1954). One can only conjecture on the results of this increase on the lung structure (apart from its function), but if the work of Cudkowicz and Armstrong (1953) on the effects on the lung of increased bronchial flow is applicable an explanation is afforded for some of the apparently inexplicable features of the lung changes found in intralobar sequestration. This concept is not new. A number of observers have been uncertain of the part played by the aberrant artery in the production of the established clinical picture. Discussing the theories of pathogenesis Tosatti and Gravel (1951) accept two as worth special mention; one concerning the maldevelopment of lung buds, the other that the formation of the lung cysts depends on congenital or acquired alteration in the lung circulation. They state:

" Either mechanical effects, such as pressure of the anomalous artery, would cause the cyst, or else this vessel, being abnormal, might hamper the proper circulation of the lung, with subsequent cystic degeneration."

They summarize previous observers' findings on the subject of the blood supply to cystic areas of lung, but offer no precise explanation of the design involved in the production of the structural abnormality. It may be simply as Maier (1954) suggests that the larger the systemic flow of blood to the lung the greater are the chances of superadded infection in that area. It is obviously not possible to offer an accurate record of the effects of the aberrant artery, but there are certain gross anatomical abnormalities, such as the presence of displaced fragments of cartilage in the sequestrated mass, which cannot be ascribed to the aberrant artery other than in the part this vessel plays in producing the developmental abnormality in the embryo.

Relationship of the Aberrant Artery to the LuNG CHANGes.-The hypothesis that certain of the lung changes may arise after birth due to the influence of a systemic circulation to the lung cannot be proved. Certain features of the cases described and those previously reported may be discussed from the point of view of this hypothesis and the accepted theory of sequestration.

(a) The characteristic lung bud lesion may be concisely described as a single cyst lined by bronchial epithelium sharply demarcated from normal lung. This is an infrequent finding where an aberrant blood supply exists in addition. The usual finding when the principal lung lesion in intralobar sequestration is of the single-cyst type is a cyst surrounded by fibrosis, dilated bronchi, and pneumonitis. The white or yellowish white area of fibrosis around the main lesion is frequently referred to in reports. The absence of sharp demarcation from normal lung has been noted by several authors (see Table 1). Cases 3 and 4 of the present series 
showed a marked degree of ill definition between normal and diseased lung. The differences in the appearances of the surrounding lung in cases of bronchogenic cyst and the monocystic type of lesion in intralobar sequestration would appear to be a result of the presence of the aberrant artery. Whether this arises from the systemic nature of the circulation or is a result of an embryological maldevelopment is the point at issue, and it is only possible to state that a lesion of the developing lung bud may arise without there being any obvious factor producing traction on the bud. The picture is materially different when such a factor, in the form of a systemic artery, is distributed to the lobe involved.

(b) The distribution and relations of the artery to the mass suggest an influence other than on the developing lung bud. The maximal lung disruption is found around the course of the artery, frequently at the point where it enters the postero-medial aspect of the lower lobe involved. This suggests that the artery is directly concerned in these lung changes, possibly through exposure to systemic blood pressure at the site where the blood flow is most free. In Cases 3 and 4 the artery runs through the centre of a structureless tissue mass which surrounds it as a collar. If the artery exerted traction on, and amputated, lung buds, it might be expected to course between the normal and the abnormal lung and be itself the dividing line between normal and diseased lung. This is not described except where a single cyst exists (Case 4, Bruwer and others, 1954). The portion of the lobe which is most nearly normal is that furthest from the main distribution of the artery, that is, in the apical and anterior basic segments of the lower lobe. The point of entry of the artery to the lobe is fairly constant, but in only one of the previously described cases has a sequestered polycystic mass been found in the apical segment (Case 1 of Tosatti and Gravel, 1951). This finding of normal lung in the apical and anterior basic segments of the lower lobe is, with the exception just mentioned, a constant feature of the cases described, and it is to these segments of the lobe that large branches of the aberrant artery cannot be traced. There appears to be, therefore, a gradual diminution of lung change as the aberrant artery branches and distributes itself towards the periphery where the preponderance of systemic over pulmonary circulation will be least. Again, it might be expected, if traction by the artery amputates and pulls on a lung bud, that a combined intralobar and extralobar lesion would be more frequent. By definition the sequestered tissue must be confined to the lobe, but there is no record of the lobe being pulled on or tented up by the artery except in three instances (Case 7 of Pryce and others, 1947; Case 5 of Kergin, 1952; Case 4 of Santy, Bérard, Galy, and Huu, 1952). In these cases a projection from the mediastinal aspect of the lobe in close relationship to the artery was noted at operation. In Case 3 of this series a right-sided lesion, a portion of structureless tissue forming the collar to the artery (Fig. 5) and continuous with the lobe, was carried well into the mediastinum anterior to the oesophagus. It was in fact necessary to leave a fragment of this tissue when dividing the artery, as the ultimate extent of its mediastinal penetration could not safely be defined. This finding appears to be strong evidence in favour of the sequestration theory, and has only been previously reported in these three right-sided lesions.

(c) The constancy of the situation of the lung changes, namely in the posterior basic segment, is believed to be due to the sequestration occurring at a uniform time during the embryological development (Bruwer and others, 1954). In sharp contrast to this is the wide variation in the point of origin, size, and extrapulmonary course taken by the aberrant artery. The aberrant arterial supply may be multiple. The vessel may be a branch of the thoracic or the abdominal aorta or it may arise from an intercostal artery as in Case 1 of this series and Case 5 of Kergin's (1952) series. It may supply normal lung (McCotter, 1910) or be bilateral and supply normal lung on each side (Natucci, 1939), and if sequestration away from the lower lobe may be considered, the aberrant supply may originate away from the aorta as in the case described by Abul-Wafa (1954). In this case a bronchial cyst in the right upper lobe was supplied by a vessel from the internal mammary artery. It is not easy to reconcile this variation in the factor producing traction on the lung bud with so uniform an end-result, as far as the situation of the lung lesion is concerned. Finally, the age at which this congenital lesion becomes manifest may be significant. It has not been possible to trace in the literature a report of the established condition being found at necropsy on an infant dead from some other cause in the neonatal period. This may well be a measure of the rarity of the disease and have no importance. On the other hand, symptoms have been late in appearing in most cases. The average age of the patient in the cases tabulated (at the time of operation) is 25 years.

The analysis of the cases was made in the belief that a relationship between the aberrant artery and the type or extent of the lung lesion would be demonstrable. This has not proved to be the case, and while there are obvious limitations to this method of obtaining information on such a detail, 
it has failed to demonstrate any association between the large artery and advanced lung changes. An unexpected finding is the high proportion $(84 \%)$ of aberrant arteries originating from the thoracic (supradiaphragmatic) aorta. From these cases and a study of cases of aberrant arteries to normal lung two assumptions are permissible. These are that the larger the aberrant artery the more cephalad its origin from the aorta, and that the aberrant artery to normal lung is more likely to originate below than above the diaphragm and to be small. The latter receives support from the findings of Findley and Maier (1951). Reporting on eight patients with aberrant arteries arising from below the diaphragm, they found the artery ran to normal lung in four. It is certain that intralobar sequestration is more common on the left than on the right. Twenty-seven of the cases from Table I are left sided, 20 right sided. Pryce and others (1947) remarked on the preponderance of left-sided lesions in a lower accessory lobe, and explained this by the fact that this condition arises at a later embryonic stage than intralobar sequestration and is associated with a bulging of the heart to the left.

\section{SUMMARY}

Four cases of intralobar sequestration of lung are described.

The possible effects of the systemic aberrant arterial circulation on the lung structure are discussed.

An analysis of 43 cases published in the last seven years is included with a view to establishing an association between the lung lesion and the aberrant artery. No interdependence between the two components of the abnormality is demonstrable with any certainty, other than that of the accepted theory of sequestration.

My thanks are due to Mr. J. Leigh Collis for the details of Case 1 and to Dr. A. P. Prior and Dr. F. Kurrein for the pathological reports. The photographs were prepared by the staff of the Central Pathological Laboratory, Warwick. Case 4 was under the care of Dr. E. N. Moyes, Case 1 of Dr. M. E. MacGregor, and Cases 2 and 3 of Dr. J. Sharkey.

\section{REFERENCES}

Abul-Wafa, M. (1954). Thorax, 9, 167.

Ameuille, P., and Lemoine, J. M. (1934). Bull Soc. méd. Hôp. Paris, 5u, l649.

Ibid., 49, 292.

Baar, H. S., and d'Abreu, A. L. (1949). Brit. J. Surg., 37, 220.

Bruwer, A., Clagett, O. T., and McDonald, J. R. (1950). J. thorac. Surg., 19, 957.

C. Amer. J. Roentgenol., 71, 751.

Cockett, F. B., and Vass, C. C. N. (1950). Brit. J. Surg., 38, 97.

Cole, F. H., Alley, F. H., and Jones, R. S. (1951). Surg. Gynec. Obstet., 93, 589.

Cudkowicz, L., and Armstrong, J. B. (1953). Thorax, 8, 46.

Ellis, F. H., Grindlay, J. H., and Edwards, J. E. (1951). Surgery, 30, 810 .

Findlay, C. W., and 1953 . J. thorac. Surg., 25, 358.

Journal of the American Medical Association (1954), 155, 840. Leading article.

Kergin, F. G. (1952). J. thorac. Surg., 23, 55.

Liebow, A. A., Hales, M. R., and Lindskog, G. E. (1949). Amer. J. Path., 25, 211.

Madoff, I. M. (1954). J. thorac. Surg., 28, 161.

Maier, H. C. (1954). Ibid., 28, 145.

McCotter, R. E. (1910). Anat. Rec., 4, 291

McDowell, C., Robb, D., Hinds, J. R., and Nicks, R. (1951). Brit. J. Surg., $39,87$.

Natucci, G. (1939). Pathologica, 31, 514. Quoted by Bruwer et al. (1954).

Pryce, D. M. (1946). J. Path. Bact., 58, 457.

Sellors, T. H., and Blair, L. G. (1947). Brit. J. Surg., 35, 18 Santy, P., Bírard, M., Galy, P., and Huu, N. (1952). J. fran?. Méd. Chir. thorac., 6, 101.

Tobin, C. E. (1952). Surg. Gynec. Obstet., 95, 741.

Tosatti, E., and Gravel, J. A. (1951). Thorax, 6, 82

Wyman, S. M., and Eyler, W. R. (1952). Radiology, 59, 658. 